\title{
Linkages creation and economic diversification: The case of Muslim countries
}

\author{
Amer Al-Roubaie \\ Ahlia University, Business and Finance, 10878 Manama, Kingdom of Bahrain \\ aalroubaie@ahlia.edu.bh
}

\begin{abstract}
Economic diversification increases the ability of the economy to produce goods and services. In developing countries, including oil producers, high degree of dependence on limited number of commodities for exports could make the economy vulnerable to changes in global markets. Recent decline in oil prices has been responsible for budget deficits, inflation, unemployment, currency devaluation and financial instability. Economic diversification balances development by reducing the risk of high degree of trade concentration. This paper highlights the importance of economic diversification for promoting development in Muslim countries. Restructuring the productive system through knowledge creation, innovation and industrialization allows the economy to generate linkages and stimulates sectoral productivity. The paper examines the causes and consequences of high dependency on trade. Muslim countries must initiate policies to increase cooperation, invest in human capital, attract FDI and increase integration in the digital economy.
\end{abstract}

\section{Introduction}

Economic development is a process of structural transformation which requires allocation of productive resources to strengthen linkage creation and foster economic growth. Economic diversification entails reducing the risk of global vulnerability by widening the productive base and minimizing economic dependence on a limited number of products. A high degree of commodity and marketing concentration typically subjects an economy to commensurate instability brought about by external forces including changes in demand and prices of primary commodities in global markets. Such dynamics create uncertainty with respect to future development prospects that translates into a reduction in confidence in the national economy and reticence on the part of investors in investing in the domestic market. The decline in oil prices in recent years has increased urgency among oil producing countries to restructure economic output and broaden economic diversification to reduce the impact of global cyclical fluctuations associated with any singular commodity.

The objective of this paper is to highlight the importance of economic diversification in fostering economic growth and sustaining development. Widening the economic base reduces the impact of external shocks on the economy by promoting macroeconomic stability and increasing investors' confidence in development. The aim of the paper is to

*Corresponding author: aalroubaie@ ahlia.edu.bh

(C) The Authors, published by EDP Sciences. This is an open access article distributed under the terms of the Creative Commons 
shed light on the importance of linkage creation as a means to induce diversification and enhance productivity of other sectors in the economy. Initiatives by governments to restructure the economic system will require institutional support to increase the stock of human capital, promote innovation, create knowledge and deepen integration in the global economy. Economic diversification requires inputs from both the public and private sectors to enhance the country readiness to create and strengthen linkages fostering the competiveness of the economy. Economic development is a process of structural transformation which requires the participation of every element of society. This paper underscores the importance of economic diversification as a means to enable Muslim countries to reduce their export dependence on a narrow range of volatile commodities in global markets. A large number of Muslim countries exhibit a high degree of trade concentration - a gauge of economic and financial vulnerability.

\section{Export-led growth development}

The relationship between international trade and economic development has been extensively debated in the literature on development studies reflecting the importance of export trade in generating economic growth. International trade is viewed as an engine of growth providing countries with the required foreign exchange to pay for international obligations and support development. The developing countries, in particular, have been dependent on export earnings to finance economic development and also to pay for imported consumer and capital goods. Exports from these countries are usually made of a limited number of primary commodities, mainly minerals and agricultural products, accounting for high percentage of both total exports and GDP.

Historically, developing countries dependence on international trade is explained by dependency theory which postulates that resources flow from a poor country a "periphery" to a "core" or rich country. Over time, transfer of resources has caused deterioration in the terms of trade for developing countries compared to that of developed ones. As a consequence, the deterioration in terms of trade of the developing countries has reduced their ability to purchase manufactured goods and promote industrialization, i.e., the decline in prices of primary commodities has deflated the real purchasing power of developing countries. In other words, high degrees of trade concentration has increased dependency of developing countries on international trade weakening, in the process, trade linkages and reducing the ability of these countries to build capacity for industrialization. Production of industrial goods is associated with high productivity and greater economic diversification.

In most developing countries, including Muslim nations, export-led growth development has failed to diversify the economic structure and foster economic growth. Heavy dependence on international trade has increased commodity concentration in tandem with demand for export revenues to meet government expenditures and pay for public services. However, a large percentage of these revenues leaked outside the economic system to pay for imported consumer and defense goods. In both cases, leakages reduced the multiplier effects of the export sector; this reduction served to depress aggregate demand and discouraged local producers from taking part in the economy. Weak multipliers discourage local producers from investing in other sectors of the economy apart from a limited range of volatile commodities for export and act as a drag on productivity.

In this age of globalization, trade allows countries to acquire knowledge, finance, technology and skills to support development. Integration into the global economy enables 
countries to promote innovation and enhances diversification. Global Value Chains (GVCs) present developing countries with new opportunities to participate in international trade and supply intermediate goods to multinational corporations. Involvement in such activities could benefit developing countries as a fillip to upgrade technologies, enhance technological learning and diversify the economy. (United Nations, 2014)

The share of trade in total world traded for selected regions and countries is shown in Table 1. For example, the share of the Organization of Islamic Countries (OIC) representing more than 50 countries accounted for 9.4 percent in 2016 compared to 59.3 for OECD countries and 12.3 percent for China during the same year. The table also illustrates that in 2016 the share of Asia in total world trade accounted for 40.8 percent compared to 2.2 percent for Africa, 4.6 percent for Arab countries and 7.2 percent for ASEAN. Low share in total trade reflects a lack of economic diversification and a higher dependency of these countries on production and export of primary commodities.

Table 1.Share of trade in total world trade for selected countries, (\%), 2000-2016

Source: UNCTADSTAT http://unctadstat.unctad.org/wds/TableViewer/tableView.aspx

\begin{tabular}{|l|l|l|}
\hline Region/country & $\mathbf{2 0 0 0}$ & $\mathbf{2 0 1 6}$ \\
\hline OECD & 71.3 & 59.3 \\
\hline Japan & 7.4 & 3.60 \\
\hline China & 3.9 & 12.33 \\
\hline OIC & 8.6 & 9.4 \\
\hline OPEC & 5.8 & 5.9 \\
\hline Arab states & 4.8 & 4.6 \\
\hline Arab Maghreb & 0.8 & 0.45 \\
\hline GCC & 2.7 & 3.7 \\
\hline Sub Saharan Africa & 1.5 & 1.6 \\
\hline Africa & 2.3 & 2.2 \\
\hline Asia & 32.0 & 40.8 \\
\hline ASEAN & 6.7 & 7.2 \\
\hline Egypt & 0.08 & 0.16 \\
\hline Indonesia & 1.01 & 0.91 \\
\hline Malaysia & 1.52 & 1.23 \\
\hline Pakistan & 0.14 & 0.13 \\
\hline Saudi Arabia & 1.20 & 1.80 \\
\hline Turkey & 0.43 & 0.87 \\
\hline
\end{tabular}

In the case of oil producing countries, high dependency on oil production and exports discouraged these countries from undertaking balanced development by investing in nonenergy sectors of the economy. Until the plummeting of global energy prices, the oil and gas export sector provided these countries with the sufficient revenue to meet public expenditures. However, the capital intensive energy sectors produced very little linkages to create incentives for local suppliers to participate in the economy. As a consequence, weak linkages created enclaves by keeping the traditional sectors isolated from the leading export sector. The private sector remained largely inactive in development as a result of government subsidies and public sector control over market activities. Oil and gas revenues were adequate to fund the expenditures of welfare states without the need for local 
enterprises to produce goods and services for domestic consumption. "The oil curse is at the origin of the Arab rentier state's autocracy, technological backwardness and economic fragility and social injustice. The Arab region has managed to squander its considerable oil wealth with unsustainable pattern of production, pricing and consumption that have created some of the highest levels of energy intensity per dollar of GDP in the world. It has also hindered any serious scientific research endeavor in renewable energy and in some countries like Yemen it has led to rapid depletion of under-ground water resources...thus the mismanagement of natural resources in Arab countries provides the strongest example of compounded failures in governance and economic policy." (United Nations, 2011, P. 6)

Instead of producing goods at home to meet rising demand for manufactured goods, Muslim countries continue to depend on imports of industrial goods needed for development. In most Muslim countries, natural resources, including energy and minerals, are kept under public ownership, which has served to weaken the role that the private sector plays in the management and processing of these resources. Non-active participation of the private sector not only weakened linkages creation in the rest of the economy, but also reduced the contribution of the private sector to job creation, innovation, and economic diversification. Greater involvement of private firms increases the potential for linkage creation, which stimulates growth and support economic diversification. (Adeel Malik, 2016; Rice University 2017).

\section{Economic diversification}

A diversified economy is defined as one that not "overly dependent on a single commodity and that has a strong external as well as internal focus." (Booz\&Co, 2008, P. 1) In such an economy, the source of output, measured by the GDP, is the cumulative output produced by a wide range of market activities each of which represents small share of the aggregate output. A diversified productive system enjoys some degree of economic stability because of the low concentration ratio of one or limited numbers of sectors.

Diversification of the productive structure enhances development by strengthening linkages creation and providing new opportunities for local firms. Export diversification has the potential to foster long term economic growth by helping local producers acquire knowledge, information, skills and technology for use to improve sectoral productivity. Acquiring information about foreign markets enhances local capabilities to produce goods that meet international standards and improve competition. Globalization provides newcomers new opportunities to operate in a bigger and highly diversified global market which offer greater access to information and knowledge about productive activities in foreign countries. In addition, export diversification reduces economic volatility by minimizing the risk of instability in export earnings. Building capacity for diversification will require institutional reforms to increase readiness and encourage investment in new industries. In most resource-based economies, revenues from export of natural resources must be reinvested in productive enterprises to generate strong linkages and increase sectoral productivity. (International Monetary Fund, 2016)

Diversification of the economic structure will require coherent industrial policy aimed at increasing sectoral productivity and reducing economic dependence on a limited number of commodities. Such policy must stimulate growth through linkages creation to enable the local economy to benefit from market activities. Setting up new industries may require local firms to supply inputs by establishing new industries and supplying new products. 
Sectors such as tourism and manufacturing exhibit a tendency to generate strong spillover effects which induce local firms to supply inputs and services to meet market demand. Local industries can benefit from both forward and backward linkages by supplying goods and services for the original industry. Lack of diversification has been among the important challenges hindering development in most Muslim countries. These countries continued to depend on extractive industries as a major source of income to support public projects and provide services for citizens. Instead of using rents from resource exploitation for investment in alternate productive sectors of the economy, these countries used revenues from production and export of natural resources to import consumer goods and pay for military equipment. Overtime, increasing dependence on the commodity export sector has rendered economies unable to generate sufficient linkages to encourage diversification. The deleterious effect of this dependency has been described by the United Nations in relation to the performance of economies in the Arab region.

"Oil-led economic growth has led to premature de-industrialization and reinforced the subordinate position of the Arab region in the global hierarchy of production. The process has been marked by unbalanced development within and between Arab countries that has hindered manufacturing and agricultural sectors and led to anaemic growth of outlying areas. As a result, entire segments of Arab societies have been left out of the growth process as country after country focused attention on growth poles in particular sectors and geographic areas without complementary policies to widen the impact of the undertaken investments." (United Nations 2011, P. 5).

To measure the productivity of the economy and determine the degree of dependency on a limited number of commodities, two indices are used: product concentration and diversification indices. The diversification index measures the competitiveness of the economy indicating that a more diversified (less concentrated) economy is more competitive, i.e. a country producing a wide range of commodities has greater advantage to compete than countries producing a limited number of commodities. On the other hand, countries with less diversified economy have limited opportunities to compete and integrate into global markets. Economic diversification has been linked to industrialization, which increases linkages creation and encourages producers to improve operations and diversify the productive system.

Similarly, a concentration ratio measures the intensity of a product in the total output of a given country, usually measured as a percentage of the country GDP. Most oil exporting countries have a high degree of product concentration due to a low level of diversification and the dominance of the energy sector in the economy. Among oil exporting economies, the share of oil exports in total exports typically represents more than two thirds of total exports whereas the share of oil exports relative to total GDP accounts for more than $50 \%$. A high degree of concentration in trade weakens potential to sustain economic growth and complicates planning for future development. In the case of primary product producers, changes in prices of these products are largely determined in the global markets, and, therefore, these economies are highly susceptible to adverse changes in global economic conditions. The degree of a country's dependence on international trade is measured by the concentration index of exports. The values given by the index range between zero (highly diversified) and one (least diversified), reflecting the variations in export concentration among nations.

Data in Table 2 illustrates that countries rich in natural resources tend to have high concentration indices reflecting high dependency of the economy on limited export commodities. On the one hand, at 0.955, Iraq's concentration index (2016) is considered 
highly undiversified. Other developing economies dependent on energy exports, including Algeria, Kuwait, Nigeria, Oman, Saudi Arabia, Qatar and UAE also exhibit high concentration indices. On the other hand, exports of economies such as the United States, China, Singapore, Turkey and Jordan are highly diversified. The table also illustrate that in 2016 exports from Organization of Islamic Countries (OIC) were more than three times as concentrated as exports from OECD countries. Similarly, the indices of export concentration from Arab countries and OPEC members were more than five times higher compared to exports from the OECD countries in the same year. A high degree of concentration reflects the vulnerability of these countries to global cyclical fluctuations and fuels uncertainty about future development. Similar patterns can be discerned with regard to the values given by the diversification index.

Table 2 also shows that the diversification indices for most Muslim countries register high values reflecting low levels of economic diversification rendering these economies more vulnerable to global shocks that hamstring their ability to balance development and hedge risks. Economies of all Muslim countries shown in table 2 have high diversification indices compared with those of OECD, the United States and China -- reflecting low sectoral productivity and high degree of commodity concentration. The diversification index for OIC countries amounts to 0.443 compared to 0.148 for OECD. Muslim countries need to formulate effective strategies to strengthen sectoral productivity and reduce the impact of global cyclical changes on development. They must invest in projects with large spillover effects to stimulate growth and encourage industrialization. Economic diversification allows countries to escape the volatility inherent in global commodity markets. Export diversification reduces economic vulnerability not only through export mix but also through marketing diversification.

Table 2. Product concentration and diversification indices, selected countries, 2016

Source: UNCTADSTAT http://unctadstat.unctad.org/wds/TableViewer/tableView.aspx

\begin{tabular}{|l|c|c|}
\hline Country & Concentration index & Diversification index \\
\hline OECD & 0.068 & 0.148 \\
\hline OIC & 0.235 & 0.443 \\
\hline OPEC & 0.375 & 0.590 \\
\hline ASEAN & 0.114 & 0.303 \\
\hline United States & 0.091 & 0.264 \\
\hline Singapore & 0.270 & 0.548 \\
\hline China & 0.077 & 0.456 \\
\hline Arab countries & 0.353 & 0.595 \\
\hline GCC & 0.355 & 0.626 \\
\hline Algeria & 0.515 & 0.835 \\
\hline Bahrain & 0.414 & 0.792 \\
\hline Egypt & 0.260 & 0.646 \\
\hline Indonesia & 0.125 & 0.489 \\
\hline Iran & 0.777 & 0.820 \\
\hline Iraq & 0.955 & 0.832 \\
\hline Jordan & 0.173 & 0.604 \\
\hline Kuwait & 0.642 & 0.847 \\
\hline Malaysia & 0.219 & 0.506 \\
\hline Morocco & 0.176 & 0.720 \\
\hline Nigeria & 0.924 & 0.888 \\
\hline Oman & 0.804 & 0.788 \\
\hline
\end{tabular}




\begin{tabular}{|l|l|l|}
\hline Pakistan & 0.215 & 0.797 \\
\hline Qatar & 0.604 & 0.842 \\
\hline Saudi Arabia & 0.687 & 0.808 \\
\hline Turkey & 0.098 & 0.583 \\
\hline UAE & 0.515 & 0.669 \\
\hline
\end{tabular}

\section{Linkages creation and diversification}

Theoretically, development linkages are produced from production of goods and services in the domestic economy or from trade with the rest of the world. An expansion of one industry may require the supply of inputs by another industry. Not being able to generate linkages with rest of the economy, due to the enclave and capital-intensive nature of extractive sector, has led to the industry's limited contribution to productivity and economic diversification (UN, 2017). Consequently, economic development in economies dependent on mineral-exportation has been stunted as evidenced by absence of economic transformation of the economy from one stage to another and stagnant productivity. In the case of oil producing countries, export of oil and gas accounted for $95.1 \%$ of total exports in Iraq, $91.8 \%$ in Algeria, $87.8 \%$ in Kuwait, $80.2 \%$ in Saudi Arabia and $86.2 \%$ in Bahrain. (IMF, 2016) The solution to the high degree of commodity concentration in these countries is to "overcome the enclaves that typically form around extractive projects, by creating an enabling environment that fosters linkages between these projects and the broader economy, thereby contributing to inclusive and sustainable development." (United Nations, 2017, P. 2)

In rentier states, the extractive sector, including energy resources, provided governments with a source of revenue to fund public services and to purchase defense goods without contributing substantially to productivity. Linkages between this extractive sector and other sectors of the economy are weak such that the latter cannot benefit from the operations of the extractive industry inasmuch as the extractive sector has fostered the creation of enclaves by keeping the rest of the economy in isolation from the export-led industry. In addition, most of these resources are not processed at home to add value to the national output and create new opportunities for local enterprises to benefit from spillover effects of the extractive industry. (Albert Hirschman, 1958) To create value, these countries need to process raw materials domestically instead of selling natural resources in a raw form. To diversify the productive structure, governments need to build linkage capacity to strengthen the relationship between extractive industries and the rest of the economy. Building such a capacity could foster economic diversification and increase productivity in the domestic economy. Support for linkages creation requires governments' creating enabling environments that encourage both domestic and international firms to invest in the local economy.

Linkage creation manifests itself in a variety of forms including forward, backward, fiscal, production, consumption, regional, horizontal and spatial linkages.

1. Forward linkages represent the benefit that the national economy obtains from processing raw materials and primary products at home instead of exporting these resources in a crude form. Processing commodities locally will require the support of local business by establishing industries to produce finished goods from the raw materials instead of exporting them in a raw form. Such activities will not only promote industrialization and create job opportunities, but also foster 
diversification of the domestic economy. Oil producing countries will be able to increase productivity and diversify the economic structure by processing at home the crude they produce instead of selling it in raw form in global markets. Industries to process raw materials and minerals make it attractive for SMEs to produce inputs and provide services for the manufactured products. Similarly, import substitution industries generate substantial linkages that stimulate business activities across sectors to supply goods and provide financial, transportation, construction, and distribution services.

2. Backward linkages involve local suppliers of goods and services contributing to the leading-export industry. Providing such inputs by local firms will require substantial levels of investment. In the case of highly capital-intensive industries, local firms may require advanced technologies and technical skills which allow technology transfer and knowledge acquisition to enhance the capabilities of local firms and encourages industrialization. The benefit to the national economy could be substantial by creating an enabling environment that promotes innovation, knowledge creation and technology diffusion.

3. Fiscal linkages strengthen the country capabilities to finance development and increase sectoral productivity. Rents from extractive industries can be used by governments to build development capacity for financing projects with high linkage creation to accelerate the process of development. Export earnings not only provide governments with income to fund their development projects, but also provide the country with the foreign exchange needed to pay for imports of capital goods and raw materials for development. In most economies in which the extractive sector predominates, including oil-exporting countries, the contribution of the sector to development has been limited. The income earned by producers is largely used by the public sector to provide services for citizens and fund the importation of luxury products consumed by the elites. Exacerbating matters, a large portion of the income earned from exports has leaked abroad reducing the power of the multiplier in the economy. In turn, this drainage has reduced the ability of affected economies to take advantage of globalization and compete successfully in the global markets. Unable to promote innovation, acquire knowledge and deepen integration in the global economy, most oil producing countries exhibit stagnant productivity growth.

4. Consumption linkages underscore the importance of spending the income earned from a leading export sector on goods and services produced locally. Theoretically, export earnings represent an important component of aggregate demand which stimulate investment expenditure and increase spending by consumers. Unlike imports which weaken the power of the multiplier due to leakage, export earnings increase the multiplier by creating new demand for goods and services. This new demand encourages local suppliers to produce more by employing locally produced inputs and hiring domestic workers. As a consequence, increase in aggregate demand enlarges stimulates production of goods and services in an economy and works to diversify its economic structure.

5. Regional linkages involve cross-border interaction through trade agreements, joint projects, economic integration, factor mobility and common currency. Small countries often lack potential to create strong linkages to stimulate economic growth. However, by improving regional cooperation, these countries will be able to gain access to a bigger market providing local firms new business opportunities in which to market their products and invest. The European Union and ASEAN are two good examples of the economic success through regional cooperation. Each serve as an alternate paradigm for GCC countries, especially for small 
economies, such as Bahrain, where expansion of regional markets could provide greater opportunities for local producers to expand their market and entrepreneurial activities creating jobs in the process serving to alleviate high rates of youth unemployment. Expansion of trade and finance among member countries through regional linkages has helped buoy productivity and economic growth on the one hand and spur diversification of economic activities on the other.

6. Horizontal linkages spur utilization of the skills, technical know-how, training and other capabilities foreign operations in the host country involving a wide range of activities spanning management, engineering, marketing, transportation, financial and other services. Acquiring knowledge and transferal of skills on the part of the host country of these activities from foreign firms can help the local economy to produce goods and services that are more competitive in global markets. Training of workers by foreign firms not only enhances labor productivity but also infuses in workers a culture of innovation that, in turn, encourages entrepreneurship leading to creation of new companies.

7. Spatial linkages resulting from building infrastructure facilitate the free movement of factors of production as well as to access to resources in an economy. Building roads, railways, electric power generation stations, storage facilitates, and ports facilitates production operations and marketing. New infrastructure benefits local producers gaining access to new markets via faster transport systems.

\section{Building diversification capacity for development}

Building capacity to diversify the economic structure and reduce the economy dependence on export of primary products requires restructuring the productive structure to ensure linkage creation and economic diversification. Through linkage creation, new industries can be established to take advantage of both market demand from and supply of inputs to the extractive sector dominant before diversification away from it is undertaken. Strengthening the creation of such linkages will require investment in industries that generate strong spillover effects to establish new industries that serve to diversify the economy. Without diversification, the economy will continue to wallow in a state of vulnerability to external shocks, the risk of which discourage both local and foreign investment in the economy. Export-led growth, driven by resource-based commodities, has led to a vicious cycle of dependence in many developing countries on volatile export earnings siphoned away from investment that would free them from such dependence. (United Nations, 2011)

The new economy, driven by globalization, is a knowledge-based economy dependent largely on innovation and human capital as key drivers of knowledge creation and economic diversification. In this regard, investment in human capital and digital technologies is essential for building productive capacity and fostering economic diversification. Governments can enhance economic performance by building infrastructure, providing incentives, promoting innovation and improving readiness. In addition, a suitable business environment must be established to encourage the investment by private sector, including entry of foreign firms, to contribute to economic restructuring and participate in the processing of raw materials in the domestic market. Within the region, greater cooperation in trade, finance and factor mobility would encourage diversification.

To promote diversification underpinning rationale development, well-formulated strategies and policies need to be articulated to create linkages. Economic policy must be 
selective by choosing projects with high linkage creation to stimulate aggregate demand and strengthen the spillover effects within and among sectors of the economy. In many resource exporting countries, there are several challenges, which need to be overcome in order to strengthen capacity-building for development. The United Nations identify some of these challenges to include: (1) access to finance; (2) lack of skills; (3) limited institutional capacity(4) lack of infrastructure (5) insufficient information flow; (6) limited involvement of civil society; and (7) Capacity to maximize interests in contract negotiations (United Nations, 2017).

The private sector is to play an important role in the knowledge-based economy driven by globalization, and, therefore, governments need not compete with the private sector in the market-place, but ought to facilities diversification through investment in human capital, physical infrastructure, research and development and digital technologies. Production of knowledge, for instance, will require highly skilled labor to improve technological learning and promote innovation. However, in most Muslim countries, the public sector still in control of key sectors in the economy with little contribution from the private in the national development. The public sector should facilitate the creation of an appropriate business environment that encourages both local enterprises and foreign firms to invest in the economy.

In this age of globalization, access to international trade provides local enterprises new opportunities to diversify lines of business as well as to compete in the global markets. Knowledge acquisition and technology transfer buoy productivity and stimulate linkages which encourage industrialization and promote innovation. The government must facilitate the integration of the local economy in the global markets by providing incentives for the private sector to gain access to global fiancé, trade, knowledge and skills.

Non-active participation of the private sector in market activities has reduced the ability of the economy to generate strong linkages and support industrialization. The capital-intensive nature of the extractive sector has discouraged local enterprises in undiversified economies from building industrial capacity and, accordingly, productivity of such economies have stagnated. In many of the resource-exporting countries, the public sector provides employment for a large number of citizens making the government sector the predominant player in such economies for creating jobs. In addition, an overweening government sector has depressed manufacturing production by skewing investment allocations toward building infrastructure, providing services and mega-projects to support the lead industry away from positive net present value investments that would have been financed in the private sector. Low levels of diversification have exacerbated the deleterious effects of the decline in oil prices on economies dependent on energy exportation in recent years. In such economies, non-oil sectors have proven unable to absorb price shocks.

\section{Economic complexity index and knowledge intensity}

The economic complexity index (ECI) measures the relative knowledge intensity of an economy. It is used to measure the knowledge content in a country's industrial composition including the knowledge intensity of the products exported by the country. The index is also used to measure the economic complexity of a country by measuring both the diversity of its exports and their sophistication. Measuring the complexity index depends on two factors, economic diversification to measure the number of products that a country can produce and economic ubiquity to measure the number of countries that are able to produce 
those products. An economy producing very limited products is considered not very complex; likewise, in the case in which these products can be produced elsewhere, the economy remains not complex. In other words, these economies are not sophisticated because of the low content of knowledge and innovative ideas used in production of these commodities. In contrast, countries such as Germany and the United States produce products which are highly specialized and may not be produced elsewhere. These economies are described as sophisticated mainly because of the knowledge and innovative ideas used in production. (See Jeff Desjardins, Which Countries Have the Most Economic Complexity?) To this end, the complexity of the economy is measured by the useful knowledge embedded in the production and exports of its products as well as it measures the knowledge accumulated in people. (http://www.visualcapitalist.com/countrieseconomic-complexity/)

In Table 3, countries with high ECI, such as Japan and Singapore, enjoy highly diversified exports with low ubiquity. In countries with low ECI, such as Pakistan, Morocco, Saudi Arabia, Kuwait and Nigeria, their exports, in contrast, are not highly diversified. Having low ECI implies that the products provided for exports have high ubiquity and that these products are not highly sophisticated. The table shows that exports from most Muslim countries, a notable exception being Malaysia, are made of primary commodities suffering from low knowledge intensity and high ubiquity. Low levels of industrialization have kept the economies of these countries highly dependent on production and export of primary products, i.e. low levels of linkages denied the productive system stimuli for diversification of the economy. In these economies, foreign technologies and knowledge boosting innovation and productivity are largely absent. Weak linkages have discouraged local producers from investing in the economy stripping it of the advantages of the new economy driven by globalization.

Table 3. Economic Complexity Index, Selected countries, 2000 - 2016

\begin{tabular}{|l|c|c|c|}
\hline Country & 2000 & 2011 & 2016 \\
\hline Switzerland & 2.19 & 1.96 & 2.60 \\
\hline Japan & 2.53 & 2.31 & 2.47 \\
\hline Singapore & 1.55 & 1.69 & 2.13 \\
\hline Malaysia & 0.64 & 0.79 & 1.03 \\
\hline Jordan & 0.23 & 0.165 & -0.01 \\
\hline Turkey & 0.10 & 0.43 & -0.04 \\
\hline Egypt & -0.37 & -0.29 & -0.41 \\
\hline Oman & -0.62 & -0.43 & -0.53 \\
\hline Algeria & -0.84 & -1.28 & -0.78 \\
\hline Pakistan & -0.84 & -0.75 & -1.07 \\
\hline Morocco & -0.66 & -0.51 & -1.09 \\
\hline Saudi Arabia & -0.10 & -0.07 & -0.36 \\
\hline Kuwait & -0.39 & -0.30 & -0.79 \\
\hline Sudan & -1.45 & -1.93 & -1.87 \\
\hline Qatar & -0.57 & -0.40 & -0.53 \\
\hline Nigeria & -2.03 & -1.71 & -1.79 \\
\hline Source: & & & \\
\hline
\end{tabular}

Source: https://atlas.media.mit.edu/en/rankings/country/eci/?year_range=2011-2016

The complexity index sheds light on the relationship between economic complexity and growth in GDP per capita. Data from transitional economies in Europe have shown that 
economic complexity is positively related to income per capita.(See http://freepolicybriefs.org/2016/03/30/economic-complexity-transition-economies/).

\section{The global value chains (GVCs)}

Over the last two decades of global business, multinational corporations have outsourced substantial components of their final products from developing countries taking advantage of cheap labor through efficient operations. Countries in Asia and Latin America have been able to integrate into Global Value Chains (GVCs) and produce intermediate goods for multinational firms acquiring, in return skills, know-how, technology, and knowledge. Through such forward linkages, these countries were able to add value to their output by diversifying the productive structure. Production of intermediate goods for manufactured products enhances industrialization and encourages local entrepreneurs to set up new industries to manufacture goods for international firms. (World Bank Group, 2017)

Global firms outsourcing intermediate goods are also engaged in upgrading technologies and providing managerial and technical skills for local firms to enhance their capabilities and supply inputs. With the exception of a few, Muslim countries have unfortunately not fully participated in globalization by integration into GVCs. The public sector, remaining dominant in most countries, provides few, if any, incentives encouraging private enterprises to be linked to GVCs and create linkages for supporting industrialization in the local economy. In the new economy, the private sector is to take the lead in diversification through capacity building for development. "The opportunities for developing linkages for natural resource sectors are determined by the capabilities of domestic firms and the effectiveness of government policy." (United nations, 2013, P. 101)

The last few decades have witnessed increase in world trade reflecting the impact that globalization and rapid advancement in information technologies had on production, marketing and distribution across the world. Modern technologies have allowed businesses to expand their operations and produce goods across geographical boundaries to reduce costs, increase efficiency, and improve competitiveness. Multinational corporations have benefited from globalization by outsourcing some components of the final products produced and distributed worldwide. For developing countries, GVCs offer new opportunities to engage in production and export of intermediate goods to acquire knowledge, skills and technology for supporting development and diversifying the economy. In particular, GVCs can increase the capabilities of SMEs to produce goods and services for international markets.

Firms located in countries with high dependency on primary commodities can join GVCs and speed up the process of development by using the existing knowledge elsewhere instead of creating their own. For these countries, integration into the GVCs will facilitate building infrastructure for industrialization and widening the economic base to improve productivity and diversify the economy. SMEs should be encouraged to participate in global production operations through linkages with global firms which will enable them to transfer technology, skills as well as obtain new technical know-how to upgrade and modernize production facilities at home. In most oil producing countries, SMEs make very little contribution to international trade, and therefore, integration in the GVCs will increase the abilities of these firms to gain greater access to global markets. Similarly, SMEs should be given greater access to regional production networks to participate in linkage creation and diversify sectoral productivity. SMEs with large stocks of human capital are most 
likely to participate in production networks and supply inputs for multinational businesses in the global markets.

Integration into the GVCs acts as a powerful development tool not only by increasing access to knowledge and skills but also by diversifying the productive system and reducing dependence on export earnings generated by a narrow range of commodities. Participating in international trade through production networks allow local producers to make use of their managerial, technical and human skills to produce goods and services for the global markets. Foreign operations set up in the domestic economy facilitate linkages creation which stimulates growth in the latter and provides incentives for local suppliers to participate in production of inputs.

\section{Conclusion}

This paper focuses on the failure of the export-led growth model revolving around the export of a narrow range of commodities to promote development in Muslim societies. Dependence on exports of raw materials, inherently volatile commodities, subjects the economies of many Muslim countries to a high degree of financial and economic instability characterized by deterioration in terms of trade and declining in export earnings brought by fluctuations in global demand and changes in prices of primary commodities in international markets. Uncertainty about future earnings has retarded development by discouraging investment and constraining growth rendering economies unable to create jobs sufficient to bring unemployment, particularly among youth, to manageable levels. In addition, revenues from export provide the necessary foreign exchange needed to import capital goods and raw materials for development. Diminution in export earnings adversely impacts balance of payments by reducing the country's ability to meet its international financial obligations. Countries hovering on the verge of, or in the full throes of, financial crisis, are rarely well-positioned to undertake sustained development.

In most Muslim countries, government expenditures are largely funded by revenues derived from export earnings to such an extent that any decline in prices of these exports disproportionately reduces the country's ability to provide public services and invest in development. In Muslim countries, moreover, economic development is driven for the most part by the ability of the public sector to fund projects involving, among others, the building of infrastructure. Accordingly, diversification reduces vulnerability by shielding national income from contraction generated by external shocks induced by high dependence on exports of commodities and by improving the terms of trade with trade partners. Undiversified economies, characteristic of a majority of Muslim countries, evince low economic complexity scores, which, in turn, are reflective of economies exhibiting low knowledge intensity in turn indicative of output being ubiquitous, with low levels of innovation, rather than specialized. In this context, Muslim countries must invest in human capital to increase the prospects for knowledge creation and innovation diffusion to capitalize on these advantages inasmuch as the new economy depends on creativity and innovation to increase productivity and diversification. Investment in human capital contributes to skill acquisition leading to innovation.

Over time, diversified economies enjoy productivity growth exceeding that of sectorally concentrated economies yielding sustainable economic growth rather than creating bubble economies set to explode once commodity prices abruptly ratchet downward as in the case of the recent collapse of petroleum prices with respect to OPEC 
economies. The export-led growth model revolving around the export of a narrow range of commodities only generates unsustainable economic growth bubbles. For, undiversified economies characterized by dependence on a leading export sector drastically curtail the ability of an economy to create linkages that, in a variety of incarnations, stimulate productivity growth: forward, backward, fiscal, production, consumption, regional, horizontal and spatial.

Effective linkage creation will require governmental adoption of policies that build manufacturing capacity across multiple industrial sectors and increase private sector contribution to development. In this vein, the government must ensure that the private sector has access to financial and technical resources to furnish multiple sectors of industry, not limited to a single export sector of primary goods, with inputs and other intermediate products produced locally. Local manufacturers should be given priority to supply manufactured products and services but without deterring foreign companies from entering into the economy inasmuch as foreign firms are vital for local firm participation in global value chains (GVCs). Deepening operations into GVCs, local firms must work to meet international quality standards and acquire knowledge and know how to satisfy final product requirements established in global markets. It is highly desirable that Muslim governments craft policies to facilitate participation of SMEs, in particular, into such GVCs.

\section{References}

Hirschman, A. (1958). The Strategy of Economic Development. New Haven: Yale University Press.

Booz\&co, (2008) Economic diversification: The Road to Sustainable Development, P. 1 https://www.strategyand.pwc.com/media/uploads/EconomicDiversification.pdf

Malik, A. (2016) Diversification of Middle Eastern Economies is more a Political than an Economic Challenge. Beirut: The Lebanese Center for Policy Studies

Africa Development Bank (2014) African Economic Outlook 2014. New York: United Nations

Hesse, H. (2008) Export Diversification and Economic Growth. Washington: World Bank Group

International Monetary Fund, (IMF), (2016) Economic Diversification in Oil-Exporting

Arab Countries. Manama, Bahrain

Rice University (2017) Economic Diversification in Gulf Cooperation Council (GCC) States. Qatar: Rice University

United Nations, (2011). Arab Development Challenges Report 2011. New York: United

Nations. Pp. 6, Pp. 5

United Nations (2013) Economic Report on Africa 2013, Making the Most of Africa's Commodities. Addis Ababa: Economic Commission for Africa P. 101

United Nations (2015) Economic Report on Africa 2015. Addis Ababa: Economic Commission for Africa

United Nations (2017), Establishing Development Linkages in the Extractive Industry: Lessons from the field. Geneva, United Nations, P.2

(http://unctad.org/meetings/en/SessionalDocuments/tdb64d3_en.pdf)

World Bank Group (2017) Measuring and Analyzing the Impact of GVCs on Economic Development. Washington: World Bank 